\title{
Sosialisasi Lesson Study for Learning Community (LSLC) Sebagai Upaya Peningkatan Mutu Pembelajaran IPA di SMP Kota Mataram
}

\author{
Hikmawati $^{1 *}$, Agus Ramdani ${ }^{1}$, Gito Hadiprayitno ${ }^{1}$, Muntari ${ }^{1}$, Mukhtar Haris ${ }^{1}$ \\ ${ }^{1}$ Jurusan Pendidikan MIPA, FKIP Universitas Mataram, Mataram, Indonesia.
}

DOI: https://doi.org/10.29303/jpmsi.v2i2.44

Citation: Hikmawati., Ramdani, A., Hadiprayitno, G., Muntari., Haris, M. 2020. Sosialisasi Lesson Study for Learning Community (LSLC) Sebagai Upaya Peningkatan Mutu Pembelajaran IPA di SMP Kota Mataram. Jurnal Pengabdian Masyarakat Sains Indonesia (JPMSI). 2(2): 108-112.

\section{Article history}

Received: June $16^{\text {th }} 2020$

Revised: June $24^{\text {th }} 2020$

Accepted: June $30^{\text {th }} 2020$

*Corresponding Author:

Hikmawati, FKIP Universitas

Mataram, Mataram, Indonesia.

Email: hikmawati@unram.ac.id

\begin{abstract}
Abstrak: Tujuan kegiatan pengabdian kepada masyarakat ini adalah untuk memberikan pemahaman bagi guru tentang Lesson Study for Learning Community (LSLC) sebagai upaya untuk meningkatkan mutu pembelajaran IPA di SMP Kota Mataram. Kegiatan ini telah dilaksanakan pada tanggal 15 Februari 2020 bertempat di SMP Negeri 20 Mataram. Peserta kegiatan sosialisasi LSLC ini terdiri atas seluruh guru di SMP Negeri 20 Mataram serta guru-guru IPA dari SMP Negeri 5 Mataram. Materi tentang LSLC yang diberikan oleh Tim kepada peserta terdiri dari 4 hal yaitu: (1) Tahapan Kolaboratif dalam LSLC; (2) Chapter and Lesson Design; (3) Teknik Observasi Saat Pembelajaran; (4) Teknik Refleksi. Setelah semua materi disampaikan oleh Tim, kegiatan dilanjutkan dengan tanya jawab tentang hal-hal yang belum dimengerti oleh peserta. Kegiatan sosialisasi ini telah memberikan pemahaman bagi guru tentang Lesson Study for Learning Community (LSLC) sebagai upaya untuk meningkatkan mutu pembelajaran IPA. Kegiatan sosialisasi ini akan dilanjutkan dengan Pendampingan Praktik Lesson Study for Learning Community (LSLC) berbasis Zonasi bagi Guru-Guru IPA SMP di Kota Mataram.
\end{abstract}

Kata kunci: Lesson study, community, mutu pembelajaran.

\section{Pendahuluan}

Untuk mencapai tujuan Pendidikan Nasional, Permendikbud Nomor 22 Tahun 2016 menegaskan perlunya proses pembelajaran yang bermutu. Penguatan mutu pembelajaran Kurikulum 2013 (K13) dapat dilakukan melalui pembelajaran inovatif berorentasi kecakapan hidup abad ke 21. Melalui learning community (LC), satuan pendidikan diharapkan dapat mengatasi kendala yang muncul di kelas melalui kerja kolaborasi antar guru, kepala sekolah, diknas, dan orang tua. Melalui Lesson study (LS) for LC memberikan kesempatan setiap anak dapat terpenuhi hak belajarnya dan merasa "nyaman" belajar di sekolah. Skala nasional secara real time, telah terpetakan SMP yang masuk pada beberapa kategori bermutu. Sekolah-sekolah tersebut perlu difasilitasi untuk mempercepat akselerasi capaian mutunya. Upaya yang didapat dilakukan oleh Dit. Pembinaan SMP adalah menyelenggarakan program pendampingan sekolah bermutu berbasis zonasi melalui lesson study for learning community (Kemendikbud, 2019).

Tidak semua guru memahami bagaimana teori dan praktik LSLC di SMP sehingga diperlukan kegiatan berupa sosialisasi tentang LSLC sebagai upaya untuk meningkatkan mutu Pendidikan IPA, khususnya di Kota Mataram. Kegiatan sosialisasi LSLC ini sesuai dengan visi dan misi sekolah, termasuk di SMPN 20 Mataram dan SMPN 5 Mataram, diantaranya yaitu: untuk meningkatkan kompetensi dan kinerja guru. Tujuan kegiatan pengabdian kepada masyarakat ini adalah untuk memberikan pemahaman bagi guru tentang Lesson Study for Learning Community (LSLC) sebagai upaya untuk meningkatkan mutu pembelajaran IPA di SMP Kota Mataram. 
Hikmawati et al, Jurnal Pengabdian Masyarakat Sains Indonesia 2020, 2 (2): 108-112. DOI : https://doi.org/10.29303/ipmsi.v2i2.44

\section{Metode}

Kegiatan pengabdian kepada masyarakat berupa sosialisasi ini dilakukan melalui ceramah oleh Tim tentang Lesson Study for Learning Community (LSLC). Setelah penyampaian materi selesai, kegiatan dilanjutkan dengan tanya jawab tentang hal-hal yang belum dimengerti oleh peserta kegiatan.

Peserta sosialisasi LSLC ini adalah guruguru yang berasal dari SMPN 20 Mataram dan SMPN 5 Mataram. Adapun materi yang disampaikan oleh Tim adalah tentang: (1) Tahapan Kolaboratif dalam LSLC; (2) Chapter and Lesson Design; (3) Teknik Observasi Saat Pembelajaran; (4) Teknik Refleksi.

\section{Hasil dan Pembahasan}

Kegiatan pengabdian kepada masyarakat ini dilaksanakan pada tanggal 15 Februari 2020 yang bertempat di SMPN 20 Mataram. Peserta kegiatan sosialisasi LSLC ini adalah semua guru di SMAN 20 Mataram dan guru-guru IPA dari SMPN 5 Mataram. Materi yang disampaikan oleh Tim pada kegiatan ini adalah sebagai berikut:

\section{1) Tahapan Kolaboratif Dalam LSLC}

Membangun kolegalitas melalui pembelajaran kolaboratif bermakna sebagai berikut: Saling menghormati harga diri guru dan menghargai karakter serta pandangan masingmasing guru; Membangun hubungan sesama guru yang dapat saling kolaborasi. Menciptakan ruang guru yang kondusif, yang memberikan kesempatan kepada guru untuk menyampaikan ide-ide positif dan berdiskusi secara terbuka; Tidak mengeluh tentang kolega, siswa, tetapi menerima mereka apa adanya dan mencari solusinya; Memiliki semangat untuk berubah dan memperbaiki diri demi meningkatkan kualitas pembelajaran.

Mengelola kelas berbasis pembelajaran kolaboratif yaitu: Menjaga harga diri siswa, menerima siswa apa adanya dan tidak memarahi siswa di depan siswa lainnya. Memberi bimbingan secara pribadi dengan suara lembut akan mendorong siswa untuk menyadari kesalahannya. Selalu berupaya agar para siswa membiasakan diri untuk saling mendengarkan sesama siswa. Mendorong siswa agar menciptakan hubungan saling kolaborasi secara positif satu sama lain. Menciptakan suasana kelas bagi siswa agar dapat secara terbuka menyatakan "Tolong ajari aku" atau
e-ISSN : 2715-2537

p-ISSN : 2715-2545

"aku belum mengerti", bagaimana cara menyelesaikan soal ini?, dsb. Sebagai seorang guru perlu memahami visi dan keyakinan yang ditunjukkan dengan kata-kata ataupun interaksi dalam kelas. Teknik Dasar untuk Pembelajaran Kolaboratif (Saling belajar) yaitu:

(1) Tahap Apersepsi yang Kreatif

Tugas apa dan bagaimana yang diberikan kepada siswa

Secepat mungkin tugas/soal diberikan kepada siswa.

Yang paling baik adalah dalam waktu $5 \sim 7$ menit setelah dimulai kegiatan.

Penjelasan guru harus singkat dan mudah dimengerti

Jika dimulai dengan kegiatan review (mempelajari ulang materi sebelumnya), semangat belajar siswa malah menurun.

(2) Membuat tugas yang menarik

a) Tugas/Soal yang mendorong siswa ingin belajar

Tugas/Soal yang seru (fun) -Menjadi ramai karena bicara

Tugas/Soal yang menarik-Menjadi sunyi/ hening

Untuk menciptakan pembelajaran kolaboratif, guru diharapkan selalu membuat tugas/soal yang menarik bagi siswa

b) Tugas/Soal yang tidak hanya sekedar untuk memperoleh pengetahuan dan keterampilan semata

Bukannya mengajar materi di buku pelajaran, melainkan belajar dengan materi di buku pelajaran.

c) Tugas/Soal yang memerlukan saling belajar Kerena dengan kemampuan sendiri tidak dapat memecahkan soal, sehingga perlu dikerjakan bersama-sama dengan kawannya

d) Tugas /Soal yang menggali hakikat materi pelajaran.

(3) Struktur Dasar Kegiatan Pembelajaran

a) Bagian Pertama dari Tahap Inti: Tugas/Soal Sharing

Mempelajari hal-hal yang harus dikuasai semua siswa

Meningkatkan kemampuan akademik kelompok siswa yang kurang mampu

b) Bagian Kedua di Tahap Inti: Tugas/Soal Jumping

Siswa berupaya untuk belajar di level yang lebih tinggi daripada sekarang, 
Hikmawati et al, Jurnal Pengabdian Masyarakat Sains Indonesia 2020, 2 (2): 108-112. DOI : https://doi.org/10.29303/ipmsi.v2i2.44

sampai akhirnya dapat menyelesaikan tugas tersebut.

Pemberian tugas ini bertujuan untuk meningkatkan kemampuan kelompok siswa yang berprestasi tinggi.

Menerapkan, mendalami dan mengembangkan pengetahuan yang telah dipelajari.

c) Refleksi

Apa yang ditemukan, baik yang dipahami maupun tidak dipahami diungkapkan oleh siswa dengan bahasanya sendiri.

Bukan pengetahuan (cara pemecahannya), melainkan cara berpikir (bagaimana memecahkannya) dapat diekspresikan oleh siswa (secara lisan maupun tertulis).

\section{2) Chapter and Lesson Design}

Chapter design bertujuan untuk memetakan pemahaman kita terhadap materi-materi dalam suatu bab (mengkonkritkan materi yang akan dipelajari siswa). Ini merupakan suatu kegiatan yang dilakukan oleh siswa untuk mencapai target materi. Model chapter design fleksibel (bisa dikembangkan sesuai selera). Langkah-langkah pengembangan chapter design: Menentukan materi yang akan dibuat chapter design. Membuat peta konsep atau mind mapping dari materi tersebut. Menentukan satu topik bahasan yang akan dibuat lesson design.

Lesson design sedikit berbeda dengan RPP pada umumnya tetapi esensinya sama. RPP berfungsi untuk memfasilitasi siswa secara klasikal. Lesson design dibuat untuk memikirkan bagaimana siswa belajar dari awal sampai akhir untuk mencapai tujuan. Dalam membuat lesson design kita memposisikan diri sebagai siswa, bukan sebagai guru. Lesson design dapat dikatakan sebagai rancangan skenario pembelajaran.

Langkah-langkah pengembangan lesson design: Menentukan satu topik bahasan yang akan dibuat lesson design. Membuat tabel yang terdiri dari 3 kolom pada manila. Menarik garis dengan spidol berwarna dimulai dari pojok kanan atas sampai pojok kiri bawah menggunakan tangan kiri. Daerah di atas garis merupakan bantuan guru untuk kegiatan siswa, sedangkan daerah di bawah garis merupakan prediksi guru tentang kegiatan siswa. Menentukan tujuan dari pembelajaran. Menentukan satu siswa (siswa yang mempunyai masalah dalam belajar). Mengidentifikasi permasalahan yang dialami oleh siswa yang kesulitan dalam belajar. Menentukan kondisi siswa yang kesulitan belajar di
e-ISSN : $2715-2537$

p-ISSN : 2715-2545

akhir pembelajaran. Mendesain kegiatan pembelajaran dimulai dari kegiatan awal, sharing task dan jumping task.

\section{3) Teknik Observasi Saat Pembelajaran}

Setiap orang dapat melihat suatu objek dengan sudut berbeda. Landasan perlunya observasi di kelas: Untuk menjamin siswa belajar sesuai dengan harapan/ ditargetkan; Untuk memperoleh gambaran bagaimana reaksi siswa terhadap aktivitas guru; Untuk melihat siswa mana yang mengalami kesulitan sehingga kita dapat memberikan bantuan belajar yang sesuai; Untuk memastikan high achievers dapat membantu temannya yang low achievers.

Panduan observasi: Sebaiknya tidak berdikusi dengan sesama observer; Boleh mengambil foto ekspresi wajah/ gerak tubuh siswa; Tidak mengaktifkan blitz dan suara smart phone; Tidak berdialog dengan siswa maupun dengan guru model; Tidak mengganggu arah pandangan siswa; Sebaiknya ikuti sesi refleksi agar mendapatkan lesson learn; Sebaiknya tidak duduk di belakang siswa agar bisa melihat ekspresi mereka, berada di posisi samping; Fokus observer adalah bagaimana siswa belajar, bukan mengamati guru/ media/ bahan ajar, dll.; Posisi observer memungkinkan mengamati ekspresi siswa; Dokumentasi dalam LSLC dapat bercerita tentang "bagaimana si Agus belajar?" Sebaiknya, dokumentasi yang diperoleh dalam observasi dapat bercerita!

\section{4) Teknik Refleksi}

Refleksi akan bermakna jika dimusyawarahkan. Refleksi adalah kesadaran sebagai jawaban suatu hal/ kegiatan yang datang dari luar. Tahapan refleksi: Duduk melingkar/ letter U; Ada moderator (leader: kepala sekolah, dinas pendidikan, pengawas, komite sekolah); Guru model dan observer menyampaikan kesan, pelajaran yang didapat \& temuannya; Observer tidak mengkritik cara guru mengajar tetapi memberi masukan; Penyampaian bahasan dari pembahas (guru senior/nara sumber/ dosen).

Tugas Pembahas: Memberikan pembahasan tentang hal-hal yang unik/baru yang diperoleh selama refleksi; Memberikan penegasan tentang prinsip pelaksanaan LSLC sesuai hasil observasi dan refleksi; Mengarahkan peserta open class untuk mendapatkan lesson learn (bagi peserta pemula); Memberikan motivasi kepada moderator, guru model, dan peserta open class.

Menurut Samani (2009), LSLC merupakan suatu model pembinaan profesi pendidik melalui 
pengkajian pembelajaran secara kolaboratif dan berkelanjutan, berlandaskan prinsip-prinsip kolegialitas yang saling membantu dalam belajar untuk membangun komunitas belajar. Peserta kegiatan LSLC tidak boleh merasa superior (merasa paling pintar) atau inferior (merasa rendah diri) tetapi semua peserta kegiatan LSLC harus mempunyai niat untuk saling belajar. Peserta yang sudah paham atau memiliki lebih banyak ilmu harus mau berbagi dengan peserta yang belum paham, sebaliknya peserta yang belum paham harus mau bertanya kepada peserta yang sudah paham. Aktivitas-aktivitas pengkajian pembelajaran tersebut akan meningkatkan komunitas belajar. Setiap siklus LSLC dilaksanakan dalam 3 (tiga) tahap, yaitu tahap pertama adalah Plan (merencanakan), tahap kedua adalah Do (melaksanakan), dan tahap ketiga adalah See (merefleksi). Tiga tahap tersebut (satu siklus) dilaksanakan secara berkelanjutan. Dengan kata lain LSLC merupakan suatu cara peningkatan mutu pendidikan yang tak pernah berakhir (continous improvement).

Cerbin \& Kopp (2006) menyimpulkan bahwa LSLC dapat mengembangkan kemampuan pedagogik dan meningkatkan kualitas mengajar guru. Ono and Ferreira (2010) mengatakan bahwa proses siklus "plan-do-see" akan mendukung pengembangan profesional guru karena guru dapat belajar dari pengalaman dan dari praktek rekan kerja sehingga berkontribusi pada peningkatan kualitas pengajaran.

Melalui LSLC, sebagaimana disarankan oleh Jufri, A.W., dkk. (2011), guru dapat berbagi pengalaman dengan guru bidang yang serumpun tentang pengelolaan kelas maupun penggunaan media pembelajaran sehingga menghasilkan perangkat pembelajaran yang inovatif dan efektif dan nantinya akan berdampak pada peningkatan kualitas pembelajaran.

\section{Kesimpulan}

Kegiatan pengabdian kepada masyarakat ini telah menambah pengetahuan peserta tentang Lesson Study for Learning Community (LSLC) sebagai upaya untuk meningkatkan mutu pembelajaran IPA di SMP Kota Mataram. Kegiatan pengabdian masyarakat dalam bentuk sosialisasi LSLC ini akan dilanjutkan dengan Pendampingan Praktik Lesson Study for Learning Community
(LSLC) berbasis Zonasi bagi Guru-Guru IPA SMP di Kota Mataram.

\section{Saran}

Perlu dilakukan pengabdian lanjutan dengan topik yang bervariatif dalam upaya meningkatkan mutu pembelajaran IPA pada tingkat Sekolah Menengah Pertama (SMP) di kota Mataram.

\section{Ucapan Terima Kasih}

Tim pengabdian mengucapkan terima kasih kepada Universitas Mataram dan LPPM UNRAM yang telah memfasilitasi kegiatan ini, dan juga kepada semua pihak yang telah mendukung pelaksanaan kegiatan ini.

\section{Daftar Pustaka}

Cerbin, W. \& Kopp, B. (2006). International Journal of Teaching and Learning in Higher Education, (2006), Volume 18, Number 250-257. http://www.isetl.org/ijtlhe/

Jufri, A. W., Agus, A.P., Gunawan, Sarjana, I.K., 2011. Pemetaan Kompetensi Peserta Didik dan Pengembangan Mutu Pendidikan SMA di Kabupaten Sumbawa dan Sumbawa Barat. Laporan Penelitian PPMP (Pemetaan dan Pengembangan Mutu Pendidikan) Tahun Anggaran 2011. Mataram: Universitas Mataram.

Kementerian Pendidikan dan Kebudayaan, Direktorat Jenderal Pendidikan Dasar dan Menengah, Direktorat Pembinaan Sekolah Menengah Pertama. 2019. Pendampingan Sekolah Bermutu Berbasis Zonasi: Materi Orientasi Program Pendampingan Sekolah Bermutu Berbasis Zonasi Melalui Lesson Study For Learning Community. Yogjakarta, 10-12 Oktober 2019.

Ono, Y., and Ferreira, J. (2010). A case study of continuing teacher professional development through lesson study in South Africa. South African Journal of Education. (2010) Volume 30, Number 1, Pages 59-74. http://www.scielo.org.za/scielo.php?script= 
Hikmawati et al, Jurnal Pengabdian Masyarakat Sains Indonesia 2020, 2 (2): 108-112.

sci_arttext\&pid=S0256-

01002010000100005\&lng=en\&nrm=iso

Samani, Muchlas. 2009. Panduan Penyusunan

Proposal: Program Perluasan dan Penguatan Lesson Study di LPTK (Lesson Study Dissemination Program for Strengthening Teacher Education in Indonesia-LEDIPSTI). Jakarta: Direktorat Ketenagaan Dirjendikti Depdiknas. 